\begin{tabular}{|l||c|c||}
\hline \hline Received 30.04.2021 & JOTS \\
\hline \hline Accepted 25.05.2021 & Review & $5 / 2$ \\
& & $2021: 418-423$ \\
\hline \hline Published 24.07.2021 & & \\
\hline
\end{tabular}

\title{
Kaygusuz, A. Buddhistische Bildersprache in alttürkischen Texten, eine literaturwissenschaftliche und philologische Analyse, Wiesbaden: Harrassowitz Verlag, 2021, S. XIV+393, ISBN: 978-3-447-11577-3
}

\author{
Deniz DEMIRYAKAN ${ }^{*}$ \\ İstanbul/ Turkey \\ E-mail:demiryakan@hotmail.com
}

Eskişehir Osmangazi Üniversitesi, Fen-Edebiyat Fakültesi, Karşılaştırmalı Edebiyat Bölümü, Doğu Dilleri ve Edebiyatları Anabilim Dalı Öğretim Görevlisi Arzu Kaygusuz, 2019 yılında tamamladığı Buddhistische Bildersprache in alttürkischen Texten: Eine literaturwissenschaftliche und philologische Analyse adl tezini bir dizi eklemeler yaparak aynı adla 2021'de yayımlamıştır.

Gerçek dünyanın görünümlerini, bireylerin farklı bakış açılarıyla yeniden yorumlayarak ürettikleri imgeleri; bir simge aracıllğıyla somut bir nesnenin üzerine yüklenen anlamı temsil eden sembolü; bir şeyi, başka bir şey kullanarak anlatan alegoriyi ve bunlara benzer tüm terimleri şu ana kadar birçok çalışma çeşitli bakış açılarıyla incelemiştir. Ancak, abecesel bir gösteren-gösterilen ilişkisinin çok ötesinde bulunan ve bireysel bir anlamlandırma söz konusu olduğundan onu anlamlandıran öznenin niteliksel, niceliksel durumu kadar varsıl olan imgesel ve sembolik anlatımın incelenmesi her bir çalışmada yeni edimlerin kapisını aralamaya devam etmektedir. Kaygusuz'un Buddhistische Bildersprache in alttürkischen Texten: Eine literaturwissenschaftliche und philologische Analyse alttürkischen adlı kitabı da bahsi geçen bu karmaşık süreci Eski Uygur

ORCID ID: 0000-0002-3565-3314. 


\section{ग(৫)}

Türkçesiyle yazılmış Budist metinleri üzerinden yeni bir aşamaya taşımaya adaydır.

İnançlar, doğaları gereği karmaşık bir yapıya sahiptir ve bu karmaşık yapı başta inanç metinleri olmak üzere birçok şeyi etkilemektedir. Bu kitabın da giriş bölümünde değinilen noktalardan biri olarak inançsal metinlerin dilsel yapısı, öngörülemez bir çerçevede ve oldukça derin unsurlardan oluşmasıdır. Unsurlar, dilsel birikimin soyut zenginlikleriyle birlikte zaman zaman bu alanda çalışanlar için de içinden çıkılamaz soru işaretlerini beraberinde getirmektedir. Eser, bu sürece, çizdiği çalışma alanı sınırlarında bir büyüteç görevi görerek elde ettiği verilerle, özelde Eski Uygur Türkçesinin, genelde ise Türk dilinin varsıllığının sınırları konusunda bizleri daha çok düşünmeye sürüklemektedir.

Kitap, yalnızca dilsel bir çalışma olmayıp aynı zamanda da edebî bir çalışmadır. Her unsur hem sözcüksel hem de sözdizimsel olarak ele alınmaktadır. Devamında da anlambilimin edinimleriyle etraflıca değerlendirilmektedir. Bu kitabın temel amaçlarından biri, Eski Uygur Türkçesiyle yazılmış Budist metinlerdeki Türkçeye özgü imgesel zenginliklere ulaşmaktır. Kitapta, temel olarak Budist inanışına yönelik metinler üzerinde çalışılmış olsa da zaman zaman Maniheist inancına yönelik metinlerdeki malzemeler de örnekleriyle incelendiğ $i$ görülmüştür. Ayrıca, din dışı metinlerin çalışma alanı ve sınırları nedeniyle göz ardı edilmeye çalışıldığı anlaşılmaktadır.

Eski Uygur Türkçesiyle yazılmış metinlerin büyük bir bölümünün Toharca, Soğdca, Sanskritçe ve Çince gibi dillerden çeviri-aktarım süreciyle Türkçeye kazandırıldığı bilinmektedir. Bu diller, o dönemi kapsayan Türk dilinin durumuyla ilgili araştırmacılara önemli ipuçları verse de eser, hem içerik hem de yazılış amacı gereği Eski Uygur Türkçesinin söz konusu dillerle ilişkisini birkaç örnekteki diller arası benzerliğin gösterimi hariç- konu almamaktadır. Daha önce de dile getirildiği üzere Eski Uygur Türkçesinin kendine özgü imgesel varsıllığına doğrudan ulaşmayı amaçlayan yazar, önceden yayımlanmış bazı akademik çalışmaları da temel alarak ilgili metinleri incelemektedir.

Anlam ve anlamın ortaya çıkışı üzerine yapılmış çalışmalar hala çok azdır. Hem sürecin karmaşıklı̆̆ı hem de işleyişin öngörülemezliği bu konuda önemli bir etkendir. Bir de inançsal metinler söz konusu olduğunda bu süreç, daha da çetrefilli bir konuma erişmektedir. Çünkü, anlam ve anlamın ardındaki 


\section{J(৫)}

unsurların iyi bir biçimde gözlemlenebilmesi, basit bir gösteren-gösterilen ilişkisinin çok dışındadır. Bu zorluğun farkında olan yazarın ilk olarak elde ettiği dilsel malzemeleri, çeşitli yönlerden sınıflandırarak çalışma alanıyla ilgili önceden yapılmış bilimsel yayımlarla temellendirdiği yaklaşım biçimiyle, birincil ve ikincil kaynaklar üzerinden incelediği görülmektedir. Böylece, metaforik vb. yapılara erişme sürecine daha etkin ve işlevsel bir dokunuşta bulunduğunu ileri sürmek yanlış olmayacaktır.

Yazarın da belirttiği üzere metin sonsuzdur. Yeniden kurma ile sonsuz sayıda tümce oluşturulabilmektedir. Peki bu sözcükler, sözcük öbekleri veya onların toplamı olan tümceler, metinler ve diğerleri; anlatım araçları açısından da sonsuz mudur? Sorunun can alıcı önemine değinen yazar, anlamlandırma sürecinin tüm bileşenlerinin iyi bir biçimde çözümlenebilmesinin ilk başta onların olabilecek en iyi şekilde tanımlanmasından geçtiğine değinmektedir. Ayrıca, anlamlandırma sürecinin daha da etkin bir biçimde saptanabilmesi için kültür ögelerine de göz atılması zorunlu olacaktır. Kültürler, şimdi olduğu gibi eskiden de birbirleriyle ilişki içindeydiler. Bu ilişkinin neticesinde de birçok bilgi alınıp verilmiştir. Bu bilgilerin arasında doğal olarak dilsel malzemeler de önemli bir yer tutmaktadır. Ancak bu dilsel malzemeler salt bir nesne olarak değil aynı zamanda imgesel ve sembolik varsıllıklarıyla kültürler arasında değişime girerek var olmuşlardır. Böylece, aynı imgesel ve sembolik yapının kaynağının neresi olabileceği sorusu önem kazanmıştır. Yazar, burada değinilen süreçle ilgili daha önceki bölümlerde olduğu gibi yine çok sayıda bilimsel yayıma ve görüşe yer vererek sürecin daha etkin anlaşılmasında önemli bir rol oynamıştır.

Kitapta, daha önce farklı bağlamlardaki makalesinde ve bildirisinde soyut adlar türeten $\{+1 \mathrm{Xg}\}$ ekine değindiği bilinen yazarın kitapta da ekin işlevine yönelik geniş bir bilgilendirmede bulunduğu görülmüştür. Kitapta yer alan örneklerin \{+lXg\} eki çerçevesinde belirlenmesinde, bazı bilimsel çalışmaların ve bilim insanlarının adları anılarak inançsal metinlerde geçen çoğu terimin Türkçede veya diğer dillerde karşılığının bulunmadı̆̆ına değinilmiştir. Eski Uygur Türkçesi özelinde de bu ekin, karşllı̆̆ bulunmayan sözcüklerin dile kazandırılmasındaki büyük işlevine dikkat çekilmiştir. Bu noktada da \{+lXg\} ekinin hem artsüremsel hem de eşsüremsel gelişimi dikkate alınarak ekin bulunduğu sözcüklerin bazı özellikler taşıdığı dile getirilmiştir. Ayrıca bu terimleri, şimdi olduğu gibi yüzyıllar önce de ilk kez duyanların anlamasının zor 
olacağı belirtilerek bu inançsal terimlerin o dili konuşanlarca kolay bir biçimde kavranabilmesini sağlamak için metaforik anlatımın kullanılmasının neden gerekli olduğu da ayrıntılı olarak ilgili bölümlerde açıklanmıştır. Bu açılamalar sonrasında da Eski Uygur Türkçesiyle yazılmış Budist inancına yönelik metinlerde söz konusu süreç bol sayıda örnekle somutlaştırılmıştır.

Yazının bu bölümüne kadar; genel hatlarıyla değindiğimiz Kaygusuz'un eseri, sekiz bölüme sahip olup bu bölümlerden ilk üçünün içerik özeti aşă̆ıdaki gibidir:

1. Bölüm (1-37): Toplamda dört alt ana başlığın bulunduğu bu bölümde, çalışmanın amacı ve kapsamıyla ilgili bilgiler verildikten sonra kitabın hangi teorik sınırlar içerisinde kalacağına değinilmiştir. Devamında ise geçmişten günümüze metafor terimine ve onun insan yaşamındaki rolüne dair bilgiler aktarılmıştır. Metaforlara yaklaşım teorileri ise ayrıca bir alt ana başlık olarak açılmıştır. Metafor kavramı, bir diğer alt ana başlıkta, başka retorik figürlerle (metonim, alegori, sembol, karşılaştırma vb.) karşılaştııılarak detaylıca değerlendirilmiştir. Bu alt ana başlığın hemen devamında ise yazar, yeni bir alt ana başlık açarak kendi çalışmasıyla ilgili olan bilimsel yayımların bilgisine değinmiş ve son olarak dördüncü alt ana başlıkta soyut adlar türeten $\{+1 \mathrm{Xg}\}$ ekine ayrıca bir başlık açarak söz konusu ekle ilgili açıklamalarda bulunmuştur.

2. Bölüm (37-39): Bu kitapta işlenen akademik sürecin hangi ilkesel temellerde yapılacağıyla ilgili bilgilerin verildiği teknik bir bölümdür. Yazar, hangi yıllar arasında yayımlanmış çalışmaları araştırmasına dahil edeceğinden başlayarak bazı işaretleme ve bildirim sembollerinin hangi amaçla kullanıldığına kadar bir dizi bilgilendirmede bulunmuştur. Böylece, birinci bölümde kullanacağı bilimsel dayanakları, ikinci bölümde de bu dayanakların işlenişindeki yol ve yöntemleri açıllayan yazar, üçüncü bölümde yazı boyunca bahsedilen süreci örneklerle somutlaştıracaktır.

3. Bölüm (39-321): Kitabın en önemli ve en hacimli bölümüdür. Eski Uygur Türkçesiyle yazılmış Budist metinlerindeki soyut adlar türeten $\{+1 \mathrm{Xg}\}$ ekiyle yapılmış dilsel malzemeler, bazı alt ana başlıklar altında tek tek değerlendirilmiştir. $\mathrm{Bu}$ alt ana başlıklardan ilki somut dilsel malzemelerle ilgilidir. Yazar, varlık alt ana başlığında insanı ve onun bazı uzuvlarını, takip eden yan alt başlıklarda incelemiştir. Bu yan alt başlık bittikten sonra meslek yan alt 


\section{四)}

başlı̆̆ına geçilerek dönemin meslekleri üzerinden metaforik kullanımlar Budist inancına yönelik metinlerle desteklenerek örneklendirilmiştir. Bunlar dışındaki yan alt başlıklarda ise suç, savaş, düşmanlık, arkadaşlık gibi kişiler ve toplumlar arası meseleler mercek altına alınmıştır. Devamındaki yan alt başlıklarda ise bazı hayvanlara ve bitkilere değinilmiştir. Böylece canlı varlıklarla ilgili metaforik ögeler bitirilmiş ve cansız varlıklarla ilgili yan başlığa geçilmiştir. Bu başlık altında da doğa ile ilgili unsurlar için oldukça detaylı bir sınıflandırılma yapılmış olup yağmurdan gök gürültüsüne; aydınlıktan karanlığa, selden doluya, dağdan ovaya birçok şeye değinilmiştir. Hatta mücevher, altın gibi değerli eşyalar da söz konusu metaforik kullanımları açısından tek tek incelenmiştir. Günlük yaşamdaki önemine binaen köprü, bahçe, yol, saray, kapı, hendek, hapishane vd. gibi yapılar da unutulmamıştır. Savaş araçlarıyla ilgili ayrıca bir yan alt başlık açılmış ve bu yan alt başlıkta silah üfleme ucundan tutun da basit yay ve oklara; marpuçtan tutun da kılıçlara kadar birçok nesne söz konusu inançsal metinlerden örneklerle ilgi çekici bir biçimde incelenmiştir. Dördüncü yan alt başlıkta ise tambur ve boynuzdan yapılan bir çalgı aletiyle ilgili metaforik kullanımlara değinildikten sonra beşinci yan alt başlıkta yine günlük yaşamda oldukça önemli olan ulaşım araçlarına ve bu araçların bazı parçalarına değinilmiştir. Devamındaki farklı bir yan alt başlıkta ise ülkeler, şehirler vd. incelenmiş ve son olarak buraya kadar bahsettiğimiz herhangi bir başlık altında değerlendirilemeyen dilsel malzemeler de diğer yan alt başlığı altında verilmiştir. Somut sözcüklerin bitimiyle yeni bir yan başlık açılarak soyut sözcüklerin metaforik kullanımlarına dair örnekler verilmeye başlanmıştır: arzu, sevinç, hırs, hayal... Doğum ve ölümle ilgili metaforik kullanımlar ise ayrıca bir yan başlıkta değerlendirilmiştir.

Son olarak buraya kadar değinilen saptamaları toparlayacak olursak, kitap, Eski Türk diliyle ilgilenenlere ve diğer bilim dallarıyla ilişkili olanlara hem dilsel hem de anlamsal malzeme açısından büyük bir zenginlik sunmaktadır. Ayrıca, özellikle dilbilimin anlambilim noktasında kanayan bir yarası olan bilimsel çalışma ve yayın eksikliği göz önünde bulundurulduğunda, bu çalışma, önemli bir işlevi yerine getirmektedir. Dilin gelişmişliğinin saptanmasında, metaforik anlatımın ne denli önemli olduğu bilinen bir gerçek olup bu anlatım gücünün aynı zamanda söz konusu dilin içkin zenginliğini de gösterdiği göz önünde bulundurulursa kitabın Türkoloji açısından da değeri daha iyi anlaşılacaktır. 


\section{J(৫)}

Günümüz koşullarında bile yabancı sözcüklere karşlık bulmadaki 'başarısızlık' her geçen gün biraz daha artarken, yüzyıllar öncesindeki dilin durumu düşünüldüğünde inançsal metinlerdeki sözcüklere bulunan karşılıkların ilk kaynaklardan örneklerle verilmesi, bu kitabın başka bir olumlu tarafıdır. 